Vol 11, Issue 9, 2018

\title{
FORMULATION AND EVALUATION OF FAST DISSOLVING FILM OF LORNOXICAM
}

\author{
ZAINAB E JASSIM*, MAIS F MOHAMMED, ZAINAB AHMED SADEQ
}

Department of Pharmaceutics, College of Pharmacy, University of Baghdad, Iraq. Email: zainabeassa@yahoo.com

Received: 03 May 2018, Revised and Accepted: 21 May 2018

\begin{abstract}
Objective: The aim of the present work was to formulate and evaluate fast dissolving film containing lornoxicam.

Materials and Methods: To prepare the film, hydroxypropyl methylcellulose E5 and polyvinyl alcohol (PVA) were used as film-forming polymers by solvent casting method. Glycerine was used as plasticizer, aspartame, and mannitol as sweetener. All prepared films were evaluated for its weight variation, disintegration time, thickness, drug content, $\mathrm{pH}$, dissolution study, and folding endurance. The drug-excipients compatibility study was
\end{abstract} done using differential scanning calorimetry (DSC) and Fourier transform infrared (FTIR).

Results: Satisfactory results obtained when PVA was used as film-forming polymer, and the drug was dispersed in the polymer solution using poloxamer 407 as a solubilizing agent. Formulation F2 is considered as the optimized formulation as it showed good folding endurance ( $>300$ ), faster disintegration rate $(30 \mathrm{~s})$, and maximum in vitro drug release (87\%) within 5 min. DSC and FTIR studies showed no interaction between drug and the polymers.

Conclusion: It can be concluded from the study that the fast dissolving film can be prepared for poorly water-soluble drug lornoxicam using PVA as a suitable film-forming polymer.

Keywords: Lornoxicam, Fast dissolving film, Hydroxypropyl methylcellulose E5, Polyvinyl alcohol, Solvent casting method.

(C) 2018 The Authors. Published by Innovare Academic Sciences Pvt Ltd. This is an open access article under the CC BY license (http://creativecommons. org/licenses/by/4. 0/) DOI: http://dx.doi.org/10.22159/ajpcr.2018.v11i9.27098

\section{INTRODUCTION}

Despite so much of advancements in various delivery systems developed for the administration of various drugs through different routes such as oral, parenteral, transdermal, and nasal, the oral route is considered as the most convenient and the preferred route of administration [1]. The oral route of administration still continues to be widely used accepted route, contributing to $50-60 \%$ of total drug formulations due to ease of administration, self-medication, and pain avoidance as compared to parenteral [2]. Fast-dissolving drug delivery is rapidly gaining interest in the pharmaceutical industry. These systems either dissolve or disintegrate generally within a minute, without needing water or chewing [3]. Difficulty in swallowing (Dysphagia) is a common problem of all age groups, especially elderly and pediatrics, because of physiological changes associated with these groups of patients [4]. Fast dissolving films are very similar to ultrathin strip of a postage stamp in their shape, size, and thickness. Fast dissolving film is simply placed on the patient's tongue or any oral mucosal tissue, instantly wet by saliva the film, and rapidly hydrates and adheres onto the site of application. It then rapidly disintegrates and dissolves to release the medication for oramucosal absorption or, with formula modifications, will maintain the quick-dissolving aspect but allow for gastrointestinal absorption to be achieved when swallowed [5].

Lornoxicam is a nonsteroidal anti-inflammatory drug (NSAID) of the oxicam class with analgesic (pain relieving), anti-inflammatory, and antipyretic (fever reducing) properties. It is available in oral and parenteral formulations. Lornoxicam inhibits the synthesis of prostaglandins through inhibition of cyclooxygenase enzyme [6]. Lornoxicam is classified as a low solubility and high permeability drug (Class II). Chemically, lornoxicam is (3E)-6-chloro- 3-[hydroxy(pyridin2-yl amino) methylene] -2-methyl-2, 3-dihydro- 4h- thieno [2, 3-e] [1,2] thiazin-4- one 1, 1-dioxide as shown in Fig. 1 [7].
The main objective of the study was to formulate and evaluate mouth-dissolving film containing lornoxicam using hydroxypropyl methylcellulose (HPMC E5) and polyvinyl alcohol (PVA) as film-forming polymers by solvent casting method.

\section{MATERIALS AND METHODS}

\section{Materials}

Lornoxicam and HPMC E5 were purchased from Wuhan Senwayer Century chemical Co., Ltd. PVA was obtained from Fine Indian chemicals. All other reagents and chemicals used were of analytical grade.

\section{Methods}

Determination of $\lambda_{\max }$

The standard solution of $100 \mu \mathrm{g} / \mathrm{ml}$ was scanned between $400 \mathrm{~nm}$ and $200 \mathrm{~nm}$ in ultraviolet (UV) spectrophotometer against phosphate buffer solution pH 6.8 as blank after baseline correction.

\section{Calibration curve of lornoxicam}

Accurately weighed $10 \mathrm{mg}$ of drug was dissolved in $10 \mathrm{ml}$ of triethanolamine $5 \% \mathrm{v} / \mathrm{v}$ and diluted to $100 \mathrm{ml}$ with phosphate buffer solution $\mathrm{pH} 6.8$ to prepare $100 \mu \mathrm{g} / \mathrm{ml}$ stock solution. The prepared stock solution was further diluted to get standard solutions of $5,7.5,10$, $12.5,15$, and $17.5 \mu \mathrm{g} / \mathrm{ml}$, and the absorbance was measured at $\lambda$ max at $376 \mathrm{~nm}$, against phosphate buffer solution pH 6.8 as blank. The standard graph was plotted by taking a concentration of drug on $\mathrm{X}$-axis and absorbance on Y-axis in the concentration range of $5-17.5 \mu \mathrm{g} / \mathrm{ml}$.

\section{Calculation of dose}

The dose of lornoxicam is $4 \mathrm{mg}$. Therefore, the amount of lornoxicam in a film of $4 \mathrm{~cm}^{2}$ is $4 \mathrm{mg}$. Area of the Petri dish of $9 \mathrm{~cm}$ diameter is 63.64 $\mathrm{cm}^{2}$ so that the amount of drug present to be added to the $63.64 \mathrm{~cm}^{2}$ area of Petri dish is $64 \mathrm{mg}$. 


\section{Preparation of HPMC E5 mouth dissolving film}

Five formulas were prepared using HPMC E5 by casting method as shown in Table 1. The specified amount HPMC polymer was weighed and dissolved in sufficient quantity of water. The solution was kept aside for overnight for swelling of polymer. Further required quantities of aspartame and mannitol (as sweetening agents since lornoxicam has bitter taste) were dissolved in $2 \mathrm{ml}$ of hot water and added to the polymer solution under continuous stirring using magnetic stirrer. Isopropyl alcohol was used as a solvent for the drug; polyethylene glycol (PEG) 400 was added to the solution as plasticizer at a concentration $20 \%$ of dry polymer. The resulting bubble-free solution was poured onto Petri dish and kept in oven at $40^{\circ} \mathrm{C}$ for $24 \mathrm{~h}$ for drying [8].

\section{Preparation of PVA film}

Films were prepared using polyvinyl alcohol by casting method as shown in Table 2. The specified amount PVA was dissolved in sufficient quantity of water at $80^{\circ} \mathrm{C}$ at hot plate. Glycerin was added to the polymer solution as a plasticizer at concentration $20 \%$ of dry polymer, and the solution was sonicated for $15 \mathrm{~min}$. Poloxamer 407 (act as a surfactant) was added to the polymeric solution with sonication. Further required aspartame and mannitol were added to the hot polymeric solution as sweetening agents. $64 \mathrm{mg}$ of lornoxicam was dispersed in the polymer solution and sonicated for $30 \mathrm{~min}$. Finally, vanilla was added as flavoring agent to the solution with sonication for $5 \mathrm{~min}$. The resulting bubblefree solution was poured onto Petri dish and kept in an oven at $40^{\circ} \mathrm{C}$ for $24 \mathrm{~h}$ for drying. The film was removed from the mold and preserved in a aluminum paper and in a desiccator.

Evaluation of lornoxicam film using PVA as a film-forming agent Appearance of films

Appearance of strip was evaluated by visual observation such as transparent and semitransparent nature of strip [9].

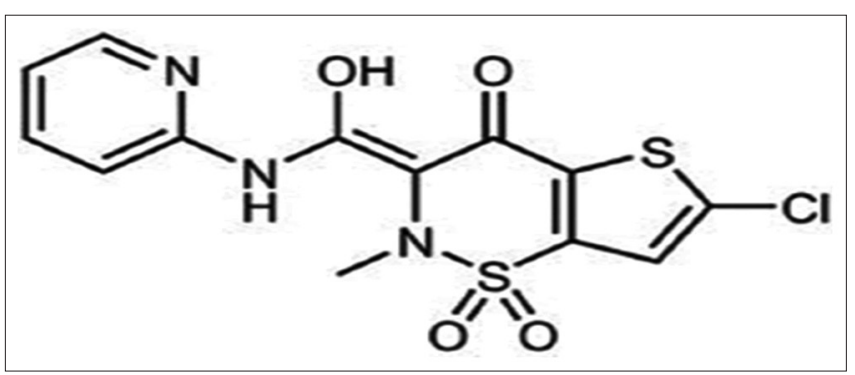

Fig. 1: Chemical structure of lornoxicam
Weight variation

10 films were randomly selected from each formulation, and the average weight variations were determined. The weight of each film was taken using digital weighing balance. The standard deviation (SD) of weight was computed from the mean value [10].

Thickness of films

The thickness of the film was measured by micrometer screw gauge (digital Vernier caliper) at five different places, at the corners, and at the center, and an average of three values and the SD were calculated. This is essential to ascertain uniformity in the thickness of the film which is directly related to the accuracy of dose in the film [11].

\section{Folding endurance}

The folding endurance was determined by repeatedly folding one film at the same place until it brokes. The number of times the film folded at the same place without breaking or cracking gives the value of folding endurance and folded up to 300 times that is satisfactory to reveal good film properties [12]

Surface $\mathrm{pH}$

The film to be tested was placed in a Petri dish and was moistened with $0.5 \mathrm{ml}$ of distilled water and kept for $30 \mathrm{~s}$. The $\mathrm{pH}$ was noted after bringing the electrode of the $\mathrm{pH}$ meter in contact with the surface of the formulation and allowing equilibration for $1 \mathrm{~min}$. The average of three determinations for each formulation was taken and the SD was calculated [13].

\section{In vitro disintegration test}

Disintegration test was performed by placing the film of size $2 \times 2$ $\mathrm{cm}^{2}$ in the glass Petri dish containing $10 \mathrm{ml}$ of water. It was stirred at every 10s time interval. The time required for the film to disintegrate was recorded, and the results are expressed as the mean of three determinations \pm SD [14]

\section{Content uniformity}

Drug content of lornoxicam films was determined by UVspectrophotometric method. For this, one strip of $4 \mathrm{~cm}^{2}$ was dissolved in $100 \mathrm{ml}$ of $\mathrm{pH} 6.8$ buffer, then the solution was suitably diluted, and the absorbance was recorded at $376 \mathrm{~nm}$ [15].

\section{In vitro dissolution studies}

In vitro dissolution of fast dissolving film was studied in USP paddle dissolution test apparatus using phosphate buffer $\mathrm{pH} 6.8$ as the dissolution medium. The temperature was maintained at $37 \pm 0.5^{\circ} \mathrm{C}$ throughout the experiment. $5 \mathrm{ml}$ sample was withdrawn at $1,2,3$, $4,5,10,15,20$, and 30 min intervals, and the same quantity was replaced with phosphate buffer of $\mathrm{pH}$ 6.8. The percentage of drug

Table 1: Formulation of lornoxicam films using HPMC E5

\begin{tabular}{llllllll}
\hline Formula & Lornoxicam (mg) & HPMC (mg) & PEG $\mathbf{4 0 0}(\mathbf{m l})$ & Aspartame (mg) & Mannitol (mg) & Water (ml) & Isopropyl alcohol (ml) \\
\hline F1 & 64 & 750 & 0.15 & 100 & 100 & q.S & 20 \\
F2 & 64 & 1000 & 0.2 & 100 & 100 & q.s & 20 \\
F3 & 64 & 1250 & 0.25 & 100 & 100 & q.s & 20 \\
F4 & 64 & 1500 & 0.3 & 100 & 100 & q.s & 20 \\
F5 & 64 & 2000 & 0.4 & 100 & 100 & q.s & 20 \\
\hline
\end{tabular}

HPMC: Hydroxypropyl methylcellulose, PEG: Polyethylene glycol

Table 2: Formulation of lornoxicam films using PVA

\begin{tabular}{lllllllll}
\hline Formula & $\begin{array}{l}\text { Lornoxicam } \\
\text { (mg) }\end{array}$ & $\begin{array}{l}\text { PVA } \\
\text { (mg) }\end{array}$ & $\begin{array}{l}\text { Glycerin } \\
\text { (mg) }\end{array}$ & $\begin{array}{l}\text { Poloxamer 407 } \\
\text { (mg) }\end{array}$ & $\begin{array}{l}\text { Aspartame } \\
\text { (mg) }\end{array}$ & $\begin{array}{l}\text { Mannitol } \\
\text { (mg) }\end{array}$ & $\begin{array}{l}\text { Vanilla } \\
\text { (m) })\end{array}$ & $\begin{array}{l}\text { Water } \\
\text { (ml) }\end{array}$ \\
\hline F1 & 64 & 400 & 80 & 120 & 45 & 45 & q.s & q.s \\
F2 & 64 & 500 & 100 & 120 & 45 & 45 & q.S & q.s \\
F3 & 64 & 600 & 120 & 120 & 45 & 45 & q.s & q.s \\
F4 & 64 & 700 & 140 & 120 & 45 & 45 & q.s & q.s \\
\hline
\end{tabular}


released was determined using UV visible spectrophotometer at $376 \mathrm{~nm}[16,17]$.

Fourier-transformed infrared (FTIR) spectroscopic analysis

FTIR spectra of pure lornoxicam, PVA, and the physical mixture of lornoxicam and PVA at ratio (1:1) were analyzed using FTIR lambda 7600-Australia spectroscopy. FTIR spectrum was recorded between 400 and $4000 \mathrm{~cm}^{-1}$ by $\mathrm{KBr}$ disc method.

\section{Differential scanning calorimetry (DSC)}

DSC thermograms were recorded using a differential scanning calorimeter (DSC-60 plus, Shimadzu). An accurately weighed sample (2-4 mg) of pure drug, PVA, and the physical mixture of lornoxicam and PVA at ratio (1:1) was heated in hermetically sealed aluminum pans under nitrogen purge $(100 \mathrm{ml} / \mathrm{min})$ over a temperature range of $25^{\circ} \mathrm{C}-300^{\circ} \mathrm{C}$ at a constant rate of $10^{\circ} \mathrm{C} / \mathrm{min}[18]$.

\section{Statistical analysis}

ANOVA test (one-way analysis of the variance) and student t-test were employed for statistical analysis. When $\mathrm{p}<0.05$, then there would be a significant statistical differences [19]

\section{RESULTS AND DISCUSSION}

\section{$\lambda_{\max }$ for pure lornoxicam in phosphate buffer solution $\mathrm{pH} 6.8$}

$100 \mu \mathrm{g} / \mathrm{ml}$ sample was prepared and scanned between 200 and $400 \mathrm{~nm}$. The drug showed maximum absorption at $376 \mathrm{~nm}$. Hence, the $\lambda_{\max }$ of lornoxicam was found to be $376 \mathrm{~nm}$ as shown in Fig. 2.

\section{Calibration curve of lornoxicam}

Lornoxicam showed maximum absorption at wavelength $376 \mathrm{~nm}$ in phosphate buffer ( $\mathrm{pH}$ 6.8) as shown in Fig. 2. Standard curve was plotted by taking absorbance of diluted stock solutions at wavelength $376 \mathrm{~nm}$. A linear relationship was obtained in Beer-Lambert's plot of lornoxicam which is shown in Fig. 3.

\section{Effect of the type of polymer as film-forming agent}

HPMC is a film-forming polymer, having excellent film-forming ability, but it had not give a satisfactory results to give a good film since the drug is water insoluble and isopropyl alcohol was not efficient to solubilize the drug and the dispersion of the drug was not achieved throughout the film, while the use of PVA gave a good film that can peel from the Petri dish and the drug was dispersed homogeneously throughout the film, so PVA was used as selected film-forming polymer.

\section{Effect of plasticizer type}

Plasticizers were used to maintain the flexibility of the films, and PEG 400 was used as plasticizer in the preparation of fast dissolving film, but it noticed that it had bitter taste affecting on the palatability of the film. Glycerin was found to be better when compared to PEG 400 since it acts as plasticizer and sweetening agent.

To improve the palatability of the mouth dissolving films, the natural sweeteners and artificial sweeteners are used in combination. Lornoxicam is being bitter in taste, and taste masking was achieved by the use of sweeteners (mannitol and aspartame) and flavors such as vanilla. Mannitol was used as natural sweetener; it was expected to give good mouthfeel and cooling sensation when incorporated with other sweeteners.

Appearance of lornoxicam film using PVA as a film-forming agent The prepared films were found to be good without any major film manufacturing defects; the film was semitransparent with yellow color since the drug has yellow to dark-yellow color as shown in Fig. 4. The surface of the film was found to be smooth; there is no sign of picking, and cracking except F1 containing 30\% of PVA was sticky and excluded from the evaluation. The other prepared films F2, F3, and F4 were evaluated for post-evaluation parameters.

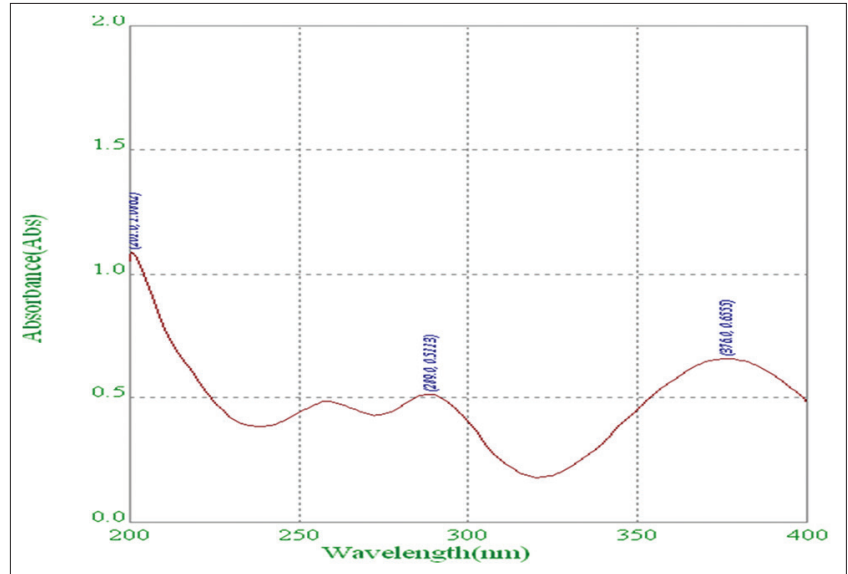

Fig. 2: Ultraviolet scan of lornoxicam in phosphate buffer solution pH 6.8

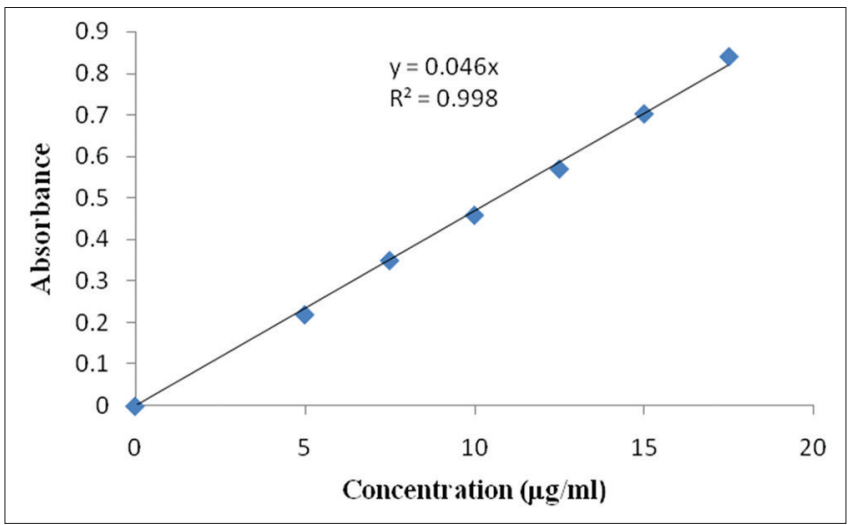

Fig. 3: Calibration curve of lornoxicam in phosphate buffer solution $\mathrm{pH} 6.8$

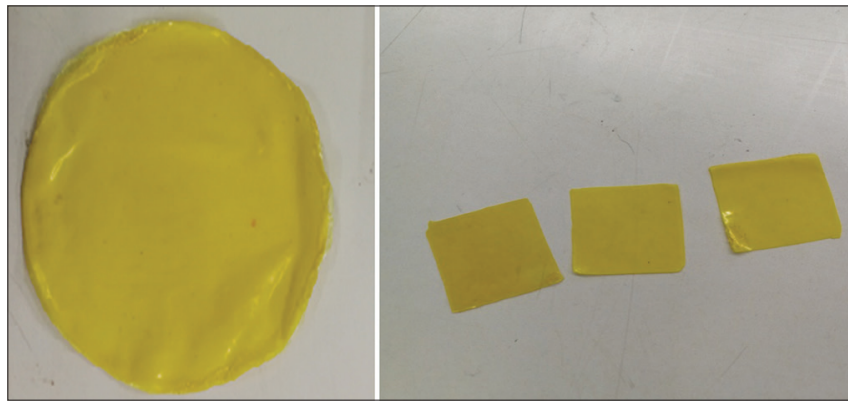

Fig.4: Fast dissolving film of lornoxicam

Weight variations

Ten films each of $4 \mathrm{~cm}^{2}$ were cut from the casted film, and weight variation was determined. Weight variation varies from $80.46 \pm 2$ to $91.44 \pm 3 \mathrm{mg}$. The result of weight variation is shown in Table 3 .

\section{Thickness}

As all the formulations contain different amount of polymers, the thickness was gradually increased with the amount of polymers. The thicknesses of formulated films were found to be in range of 0.071$0.114 \mathrm{~mm}$. The results are given in Table 3 which shows a gradual increase in the thickness.

\section{Folding endurance}

Brittleness of the film was determined through the folding endurance. It measures the ability of the film to withstand rupture. Any formulated 
Table 3: Evaluation of physicomechanical parameters of fast dissolving film of lornoxicam

\begin{tabular}{lllllll}
\hline Formula & Weight variation $(\mathbf{m g})$ & Thickness $\mathbf{( m m})$ & Folding endurance & $\mathbf{p H}$ & Disintegration time (s) & Drug content (\%) \\
\hline F2 & $82.9 \pm 1$ & $0.081 \pm 0.02$ & $>300$ & $6.76 \pm 0.12$ & $30.3 \pm 3$ & $95 \pm 1$ \\
F3 & $80.46 \pm 2$ & $0.071 \pm 0.013$ & $>300$ & $6.7 \pm 0.1$ & $41 \pm 3$ & $112 \pm 0.43$ \\
F4 & $85.1 \pm 3$ & $0.114 \pm 0.016$ & $>300$ & $6.57 \pm 0.21$ & $52 \pm 3.6$ & $96 \pm 0.1$ \\
\hline
\end{tabular}

The values represent mean \pm standard deviation, $n=3$

Table 4: In vitro dissolution studies of lornoxicam from F2 to F4

\begin{tabular}{llll}
\hline Time (min) & F2 & F3 & F4 \\
\hline 0 & 0 & 0 & 0 \\
1 & $7.16 \pm 0.08$ & $11,8 \pm 0.7$ & $9 \pm 0.03$ \\
2 & $25 \pm 0.09$ & $13.5 \pm 0.3$ & $9 \pm 0.06$ \\
3 & $51.5 \pm 0.02$ & $20.3 \pm 0.06$ & $22 \pm 0.4$ \\
4 & $77 \pm 0.04$ & $29 \pm 0.07$ & $36 \pm 0.1$ \\
5 & $87 \pm 0.1$ & $40 \pm 0.5$ & $50 \pm 0.03$ \\
10 & $95 \pm 0.045$ & $66 \pm 0.021$ & $76 \pm 0.05$ \\
15 & $98 \pm 0.2$ & $77.5 \pm 0.05$ & $82 \pm 0.06$ \\
20 & $99 \pm 0.3$ & $80 \pm 0.04$ & $87 \pm 0.063$ \\
30 & $100 \pm 0.4$ & $87 \pm 0.2$ & $93 \pm 0.09$ \\
\hline \multicolumn{2}{l}{ All values expressed as mean \pm SD (n=3), F: Formula, SD: Standard deviation }
\end{tabular}

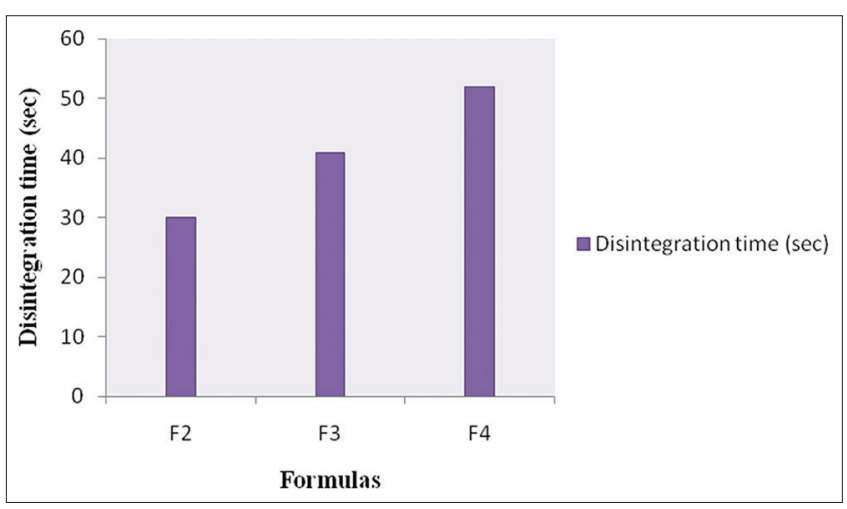

Fig. 5: Disintegration time of lornoxicam film

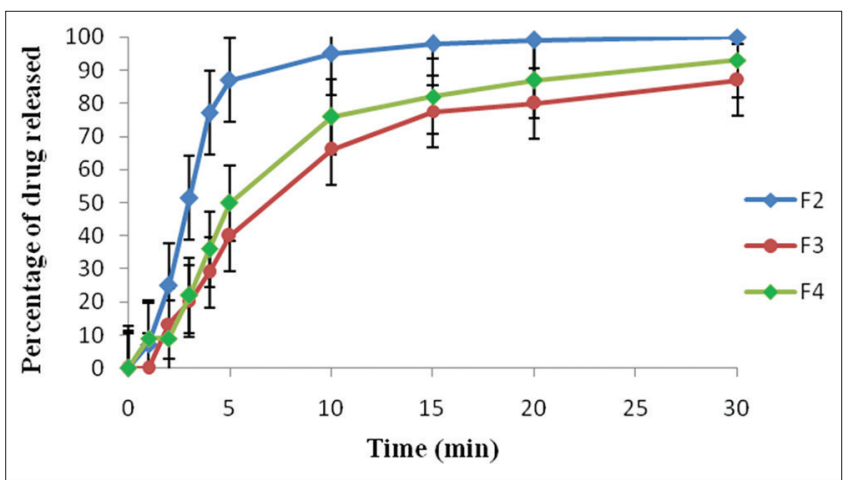

Fig. 6: Dissolution profile of lornoxicam film F2, F3, and F4. All values expressed as mean \pm standard deviation $(n=3), F=$ formula

film has a folding endurance value; a value more than 300 indicates acceptable results [19]. Glycerin acts as a plasticizer because it is capable to decrease the glass transition temperature. Lowering the glass transition temperature increases chain mobility and this, in turns, increases in folding endurance [1]. The folding endurance of all the formulations was $>300$, and the results are given in Table 3 .

\section{pH surface evaluation}

Test the $\mathrm{pH}$ of the surface of oral film needs to be done to investigate the risk of side effects. Acidic or basic $\mathrm{pH}$ may cause disturbance in the oral mucosa and impact the rate of hydration of the polymers, so it is important to maintain the $\mathrm{pH}$ remains close to neutral $\mathrm{pH}$. From Table 3, it can be seen that the film has a near neutral $\mathrm{pH}$ which is in the range of 6.57-6.76. Hence, the dosage has a very small probability to irritate the oral mucosa [20].

\section{In vitro disintegration time}

It was observed that in vitro disintegration time varies from $30.3 \pm 3$ to $52 \pm 3.6 \mathrm{~s}$ for the three formulations as demonstrated in Table 3 and Fig. 5 . In vitro disintegration time of lornoxicam film containing PVA as polymer was affected by the thickness of the film, and as the amount of polymer increases [21], the disintegration time was increased significantly $(\mathrm{p}<0.05)$ by increasing the concentration of the polymer as in $\mathrm{F} 3$ and $\mathrm{F} 4$ that contain $50 \% \mathrm{w} / \mathrm{w}$ and $55 \% \mathrm{w} / \mathrm{w}$ of PVA, respectively, while the disintegration time for F2 (40\% of PVA) was the lowest. This can be explained as the higher concentration of the polymer, the thicker gel will produce on contact with the media, which require a longer time to disintegrate [19].

\section{Content uniformity evaluation}

Content uniformity test performed to ensure that all films contain a uniform weight of drug as desired. Content uniformity is determined by estimating the active ingredient contained in each film. Limit of content uniformity is $85-115 \%$ with a SD which must be $\leq 6 \%$ [22]. From Table 3, it can be seen that the levels of drug in the film range between $95 \%$ and $112 \%$. It showed that levels of drug in oral film fulfill the limit of content uniformity.

\section{In vitro dissolution study}

The in vitro drug release from film of the three formulations was performed in triplicate using USP apparatus II (paddle method). Dissolution study was performed in $\mathrm{pH} 6.8$ phosphate buffer; the release profile was demonstrated in Fig. 6 and and Table 4 shows the percentage of drug being dissolved in $30 \mathrm{~min}$. In case of $\mathrm{F} 2$ that contains $40 \%$ of PVA formulation, about $87 \%$ of drug was released in $5 \mathrm{~min}$ and was considered as the best formulation. While in case of F3 and F4, containing $50 \%$ and $55 \% \mathrm{w} / \mathrm{w}$ of PVA, respectively, formulations about $40 \%$ and $50 \%$ of drug released, respectively, in $5 \mathrm{~min}$. This drug release pattern indicates that the increased concentration of polymer decreases the drug release.

\section{FTIR study}

The FTIR spectrum of lornoxicam (Fig. 7) has a characteristic peak at $3066 \mathrm{~cm}^{-1}$ corresponding to $-\mathrm{CH}$ starching of heteroaromatic ring, and sharp peak obtained at $1646 \mathrm{~cm}^{-1}$ represents the stretching vibration of $\mathrm{C}=0$ in structure of primary amide. Other peaks were observed at 1595 and $1549 \mathrm{~cm}^{-1}$ and were assigned to bending vibrations of the $\mathrm{N}-\mathrm{H}$ group in the secondary amide. The stretching vibrations of the $\mathrm{O}=\mathrm{S}=\mathrm{O}$ and C-S groups appeared at $1326 \mathrm{~cm}^{-1}$ and $1425.46 \mathrm{~cm}^{-1}$, respectively. Other prominent peaks was appeared at $869.74 \mathrm{~cm}^{-1}$ corresponding to $-\mathrm{CH}$ aromatic ring bending and heteroaromatics and at $790.67 \mathrm{~cm}^{-1}$ due to the $\mathrm{C}-\mathrm{Cl}$ bending vibration. $\mathrm{C}-\mathrm{N}$ stretching was observed at $1084.51 \mathrm{~cm}^{-1}$. The presence of all these groups shows similarity with actual drug structure which indicates the purity of drug substance [23].

The most characteristic band of PVA (Fig. 8) and its respective assignments is observed at $3423 \mathrm{~cm}^{-1}$ and is ascribed to the $\mathrm{O}-\mathrm{H}$ stretching from the intermolecular and intramolecular hydrogen bonds. The characteristic peaks of lornoxicam were still present in the physical mixture of drug and PVA (Fig. 9) at a ratio of 1:1, indicating no chemical interaction between the drug and polymer. 


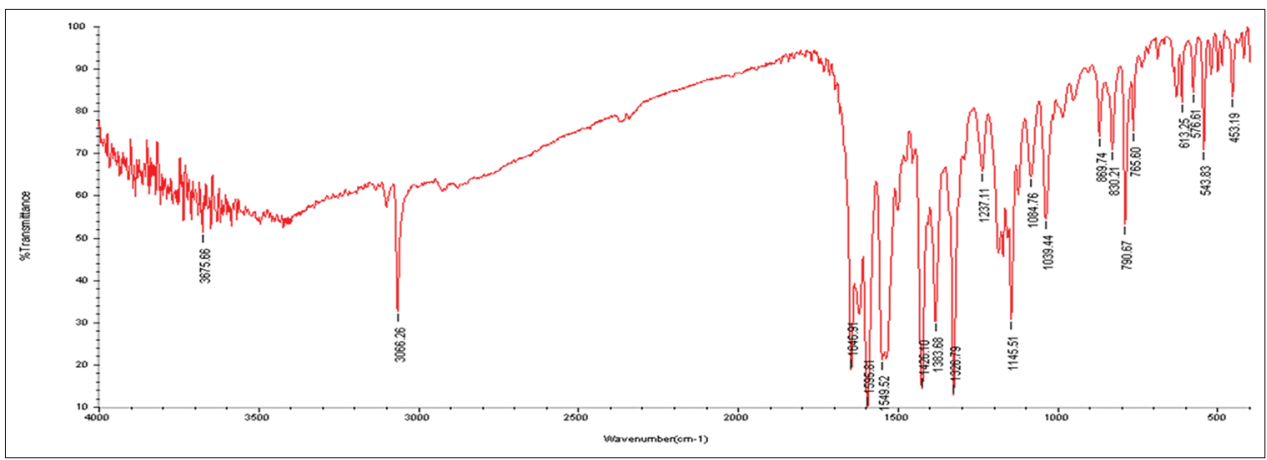

Fig. 7: Fourier transformed infrared spectrum of lornoxicam

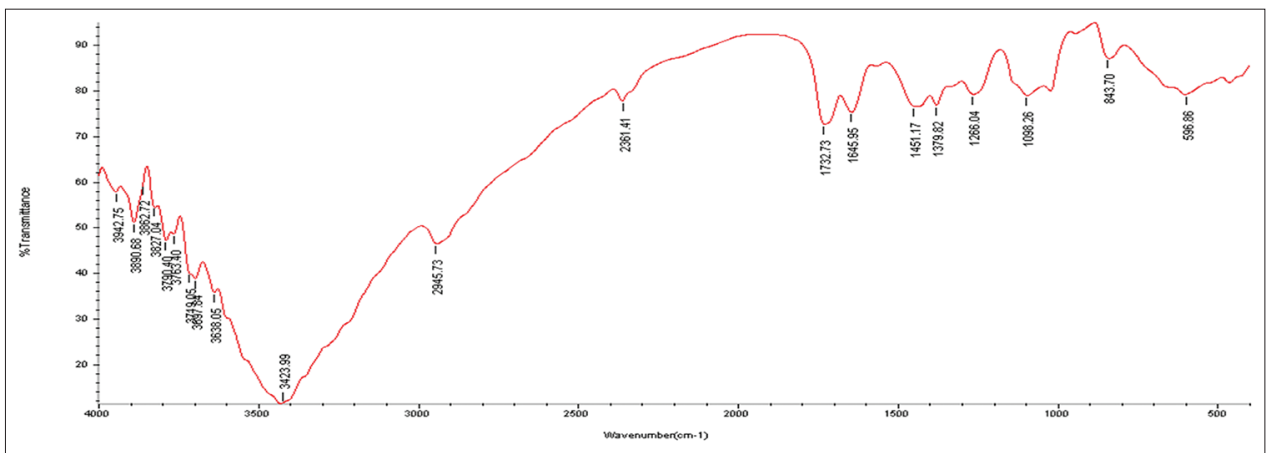

Fig. 8: Fourier transformed infrared spectrum of polyvinyl alcohol

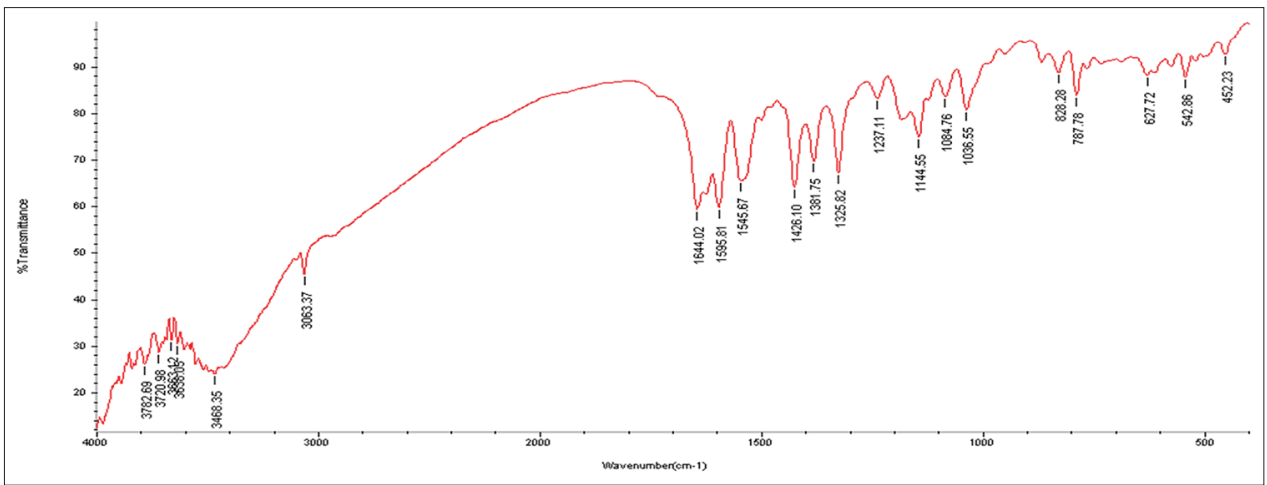

Fig. 9: Fourier transformed infrared of physical mixture of lornoxicam and polyvinyl alcohol at ratio (1:1)

DSC

DSC curves of lornoxicam, PVA, and physical mixture of lornoxicam and PVA at ratio (1:1) were obtained and shown in Figs. 10-12, respectively. Pure lornoxicam showed a sharp exothermic peak at $220^{\circ} \mathrm{C}$ which corresponds with the range of melting point of lornoxicam $(220-$ $230^{\circ} \mathrm{C}$ ), and the sharp intense exothermic peak indicates the crystalline nature of drug $[24,25]$.

The DSC curve of physical mixture showed a sharp endothermic peak at $224^{\circ} \mathrm{C}$ corresponding to melting point of lornoxicam and the exothermic peak of PVA at $191^{\circ} \mathrm{C}$ indicating that there is no interaction between lornoxicam and PVA

\section{CONCLUSION}

In the present research work, an attempt has been made to prepare mouth dissolving films of lornoxicam which is NSAID, water-insoluble with bitter taste. The fast dissolving films of lornoxicam were prepared by solvent casting method using film-forming polymer PVA and glycerol as plasticizer. Based on the in vitro disintegration time and dissolution profile, formulation F2 was found to be promising and showed a disintegration time of $30 \mathrm{~s}$ and $87 \%$ of drug released in $5 \mathrm{~min}$.

\section{ACKNOWLEDGMENT}

Authors are thankful to Dr. Ahmed Abbas Hussain and Dr. Lena Murad Thomas, for their help, and authors are also thankful to the Baghdad University, College of Pharmacy, and Department of pharmaceutics for providing the required necessary facilities.

\section{AUTHORS' CONTRIBUTION}

The three authors contributed equally to this work.

\section{CONFLICTS OF INTEREST}

The authors report no conflict of interests and are responsible for the content and writing of this article. 


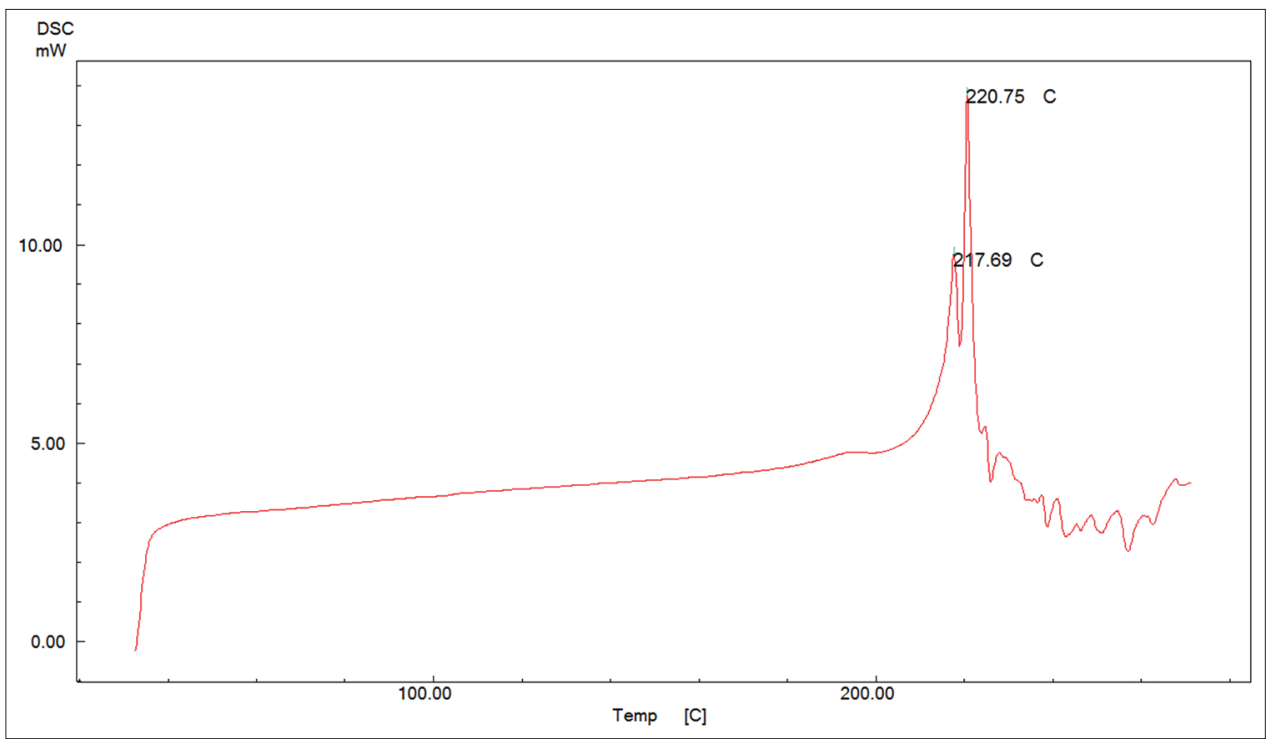

Fig. 10: Differential scanning calorimetry of lornoxicam

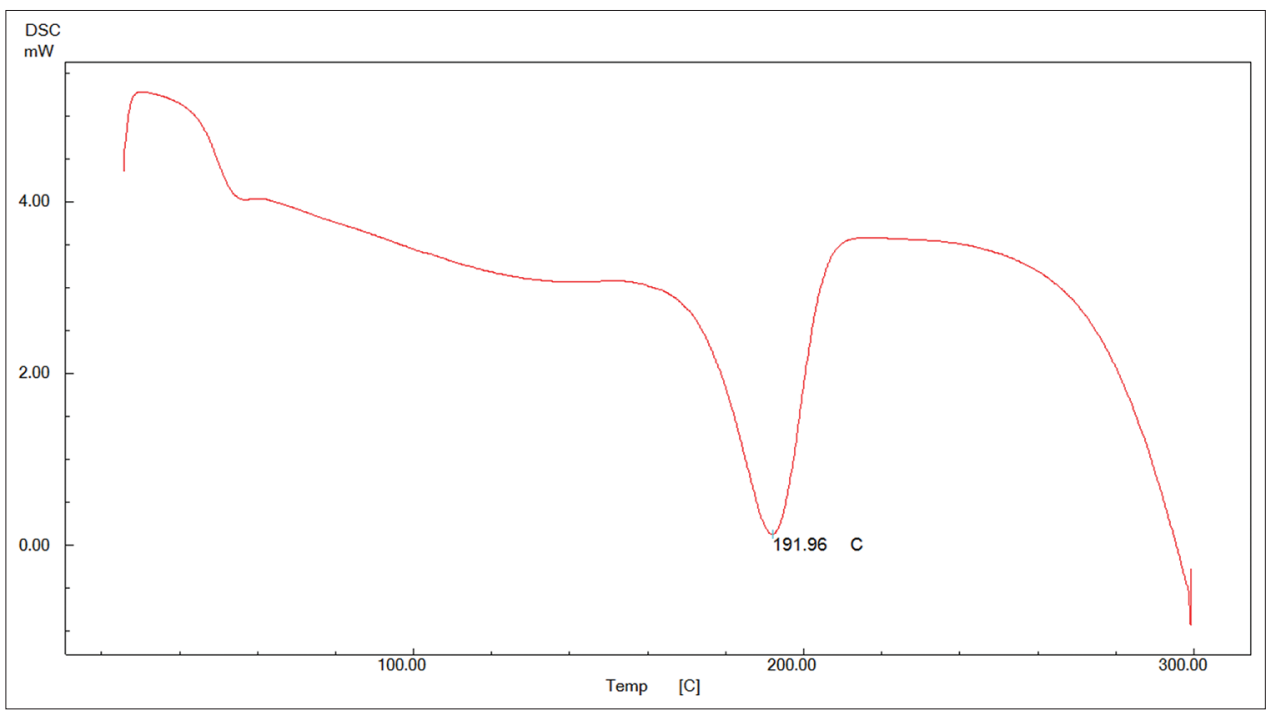

Fig. 11: Differential scanning calorimetry of polyvinyl alcohol

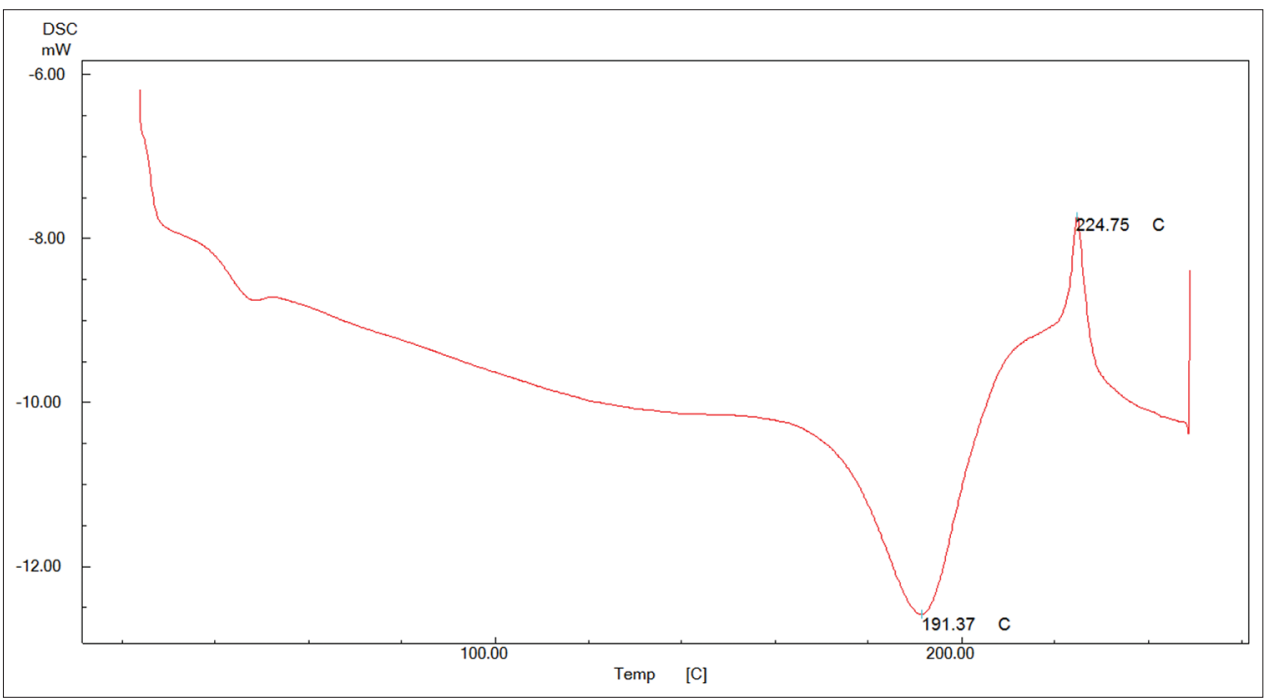

Fig. 12: Differential scanning calorimetry of physical mixture lornoxicam and polyvinyl alcohol 


\section{REFERENCES}

1. Pawar SV, Junagade M. Formulation and Evaluation of mouth dissolving film of risperidone. Drug Deliv Syst 2015;9:11.

2. Keshavarao KP, Mudit D, Gunashekara K, Anis S, Mangla NS, Ajay K. Formulation and evaluation of mouth dissolving film containing rofecoxib. Int Res J Pharm 2011;2:273-8.

3. Upreti K, Kumar L, Anand SP, Chawla V. Formulation and evaluation of mouth dissolving films of paracetamol. Int J Pharm Pharm Sci 2014;6:200-2.

4. Chaudhary H, Gauri S, Rathee P, Kumar V. Development and optimization of fast dissolving oro-dispersible films of granisetron $\mathrm{HCl}$ using box-behnken statistical design. Bull Fac Pharm Cairo Univ 2013;51:193-201.

5. Pandya K. Fast dissolving films: A novel approach to oral drug dilivery. Int J Pharm India 2013;1:385-97.

6. Ulla SN, Roy AK, Sm VK. Formulation and evaluation of sustained release matrix tablets of lornoxicam. Int J Drug Dev Res 2011;3:31-44.

7. Patil A, Patil S. Modification of physicochemical characteristics of Lornoxicam using cyclodextrin as modulator. Int J Pharm Tech Res 2012;4:201-7.

8. Kalyan S, Bansal M. Recent trends in the development of oral dissolving film. Int J PharmTech Res 2012;4:725-33.

9. Kulkarni A, Deokule H, Mane M, Ghadge D. Exploration of different polymers for use in the formulation of oral fast dissolving strips. J Curr Pharm Res 2010;2:33-5.

10. Swamy N, Kumar SS. Formulation and evaluation of fast dissolving oral films of palonosetron hydrochloride using HPMC E5. Int J Pharm Chem Sci 2014;3:145-50.

11. Dixit GR, Chavhan JI, Upadhye KP, Misra S. Formulation and characterization of mucoadhesive buccal film of ranitidine hydrochloride using sterculia foetida gum as polymer. Asian J Pharm Clin Res 2015;8:68-71.

12. Gawai N, Zaheer Z. formualtion and development of mucoadhesive sustained release buccal tablets and patches of 5-fluorouracil using different polymers. Asian J Pharm Clin Res 2018;11:174-85.

13. Bhagwat DA. Formulation and evaluation of fast dissolving buccal patch of olmesartan medoxomil. Asian J Bio Pharm Sci 2013;3:51.

14. Liu C, Chang D, Zhang X, Sui H, Kong Y, Zhu R, et al. Oral fastdissolving films containing lutein nanocrystals for improved bioavailability: formulation development, in vitro and in vivo evaluation. AAPS PharmSciTech 2017;18:2957-64.

15. Kapoor D. Fabrication and characterization of oral thin films of leukotrine receptor antagonist (LTRA). J Drug Deliv Therap 2015;5:77-82.

16. Yasmeen BR, Firoz S, Mouli YC, Vikram A, Mahitha B, Aruna U. Preparation and evaluation of oral fast dissolving films of citalopram hydrobromide. Int J Biopharm 2012;3:103-6.

17. Kalyanappa S, Krishna MR, Goli D. Design and in vitro evaluation of a novel sustained release double layered tablets of lornoxicam by using semi synthetic polymers. Indian J Pharm Educ Res 2015;49:281-91.

18. Alhalabi GF, Barakat NS, Alsulami AF, Al-Solbi AK, Shoieb BM, Alotaibi HA, et al. Formulation and evaluation of fast dissolving film of meloxicam. Int J Res in Pharmacol Pharmacother 2017;6:16-27.

19. Jaafar IS. Formulation and in vitro evaluation of fast dissolving film of metoclopramide hydrochloride. Int J ChemTech Res 2017;10:26-38

20. Reveny J, Tanuwijaya J, Remalya A. Formulation of orally dissolving film (ODF) metoclopramide using hydroxypropylmethylcellulose and polyvinyl alcohol with solvent casting method. Int J ChemTech Res 2017;10:316-21.

21. Bhupinder B, Sarita J. Formulation and evaluation of fast dissolving sublingual films of rizatriptan benzoate. Int $\mathrm{J}$ Drug Dev Res 2012;4:133-43.

22. Kathpalia H, Sule B, Gupte A. Development and evaluation of orally disintegrating film of tramadol hydrochloride. Asian J BioPharma Sci 2013;3:27-32

23. Sunita SS, Avinash HH. Preparation and evaluation of nanosuspensions for enhancing the dissolution of lornoxicam by antisolvent precipitation technique. Indo Am J Pharma Res 2014;4:398-405.

24. Dandagi PM, Dessai GA, Gadad AP, Desai VB. Formulation and evaluation of nanostructured lipid carrier (NLC) of lornoxicam. Int J Pharm Pharm Sci 2014;6:73-7.

25. Mhasal SN, Mali B, Narkhede MB. Drug-excipient interaction study of lornoxicam with polymers. Sch Academic J Pharm 2017;6:423-8. 